Писатель и история (к столетию со дня рождения Добрицы Чосича)

\begin{abstract}
Аннотация: В статье рассматривается политическая деятельность Д. Чосича, отмечается роль его документальной прозы и анализируются художественные произведения писателя сквозь призму его служения сербской нации. Отмечается признание Д. Чосича в России.
\end{abstract}

Ключевые слова: Д. Чосич, оппозиционность, история Сербии, эпический размах, драматизм

S.N. Meshcheriakov (Moscow, Russia)

\title{
The Writer and the History (On the centenary of the birth of Dobrica Ćosić)
}

Abstract: The article examines the political activity of Dobrica Ćosić, mentions the role of his documentary prose and analyzes the writer's fiction through the prism of his service to the Serbian nation. The article acknowledges the recognition that Dobrica Ćosić has earned in Russia.

Key words: Dobrica Ćosić, opposition, history of Serbia, epic scope, drama

Немногим писателям удается влиять на ход исторических событий. В марте 1941 г. полномочный министр и чрезвычайный посланник Королевства Югославии в Берлине и будущий лауреат Нобелевской премии по литературе Иво Андрич (1892-1975) пытался убедить руководство своей страны отказаться от ведения тайных сепаратных переговоров с Германией в связи с присоединением к Тройственному пакту. Попытки Андрича не увенчались успехом, а его отставка не была принята.

В 1992-1993 гг. другой сербский писатель, Д. Чосич (1921-2014), находясь на посту Президента Югославии, тщетно пытался провести преобразования в стране и предотвратить межнациональный конфликт в Боснии и Герцеговине. Через год пребывания у власти Чосич был смещен опытным политиком Президентом Сербии Н. Милошевичем при участии лидера сербских радикалов В. Шешеля. В ходе столкновения Чосич, не желая кровопролития, добровольно подал в отставку.

При этом писатель не был совершенно случайным человеком в коридорах власти. После окончания Второй мировой войны он, как участник Народно-освободительной борьбы с 1941 г., комиссар партизанского отряда, занимал важные по- 
сты в Агитпропе Югославии, был членом Скупщины (парламента) Сербии и ЦК Союза коммунистов Сербии. При этом к нему благосклонно относились первые люди страны: министр госбезопасности всесильный Александр Ранкович и даже сам Иосип Броз Тито. В 1961 г. писатель вместо с Тито совершил 72-дневный вояж на яхте «Галеб» («Чайка») по странам Западной Африки, которые придерживались политики неприсоединения.

Однако уже в 1960-е гг. Чосич выражал несогласие с политикой правительства страны. По словам самого писателя, после VIII съезда Союза коммунистов Югославии в 1964 г. начала проявляться тенденция к преобразованию страны из федерации в конфедерацию. Это вело к ослаблению ее единства и, как пишет Чосич, «К открытой сербофобии» ${ }^{1}$. В 1968 г. писатель, несогласный с примирительной политикой по отношению к албанским националистам, вышел из Союза коммунистов Югославии.

Верность собственным убеждениям при Тито была недопустимой роскошью: до этого сам Милован Джилас (1911-1995), главный идеолог страны, отклонившийся от линии партии, попал на долгие годы в тюрьму. Столь серьезный в политическом отношении акт Д. Чосича был свидетельством исключительного мужества, порядочности и честности независимо от оправданности или неоправданности его решений. В 1970 г. по рекомендации И. Андрича Д. Чосич был принят в Сербскую Академию наук и искусств.

Ни дипломату Андричу, ни президенту Чосичу не удалось своими поступками непосредственно изменить ход исторических событий. Однако писатель и общественный деятель Чосич самым серьезным образом воздействовал на пробуждение сербского национального самосознания и был впоследствии даже назван «отцом нации», что, как представляется, вряд ли льстило доброжелательному, интеллигентному и тактичному человеку.

Общественно-политическая деятельность Чосича до его избрания президентом Югославии включала в себя активное участие в создании Комитета по защите свободы слова и мысли (1984-2001), попытку издания журнала «Общественное мнение» (1980). Однако в наибольшей мере на общественное сознание воздействовала его документальная проза и особенно его художественное творчество.

Первым серьезным опытом подобного рода стало документальное повествование о венгерском восстании 1956 г. под названием «Семь дней в Будапеште». Присутствие писателя в венгерской столице в эти дни было не случайным: он был послан туда руководством Югославии для выявления подлинного характера этих событий и возможных рекомендаций по этому поводу. Начальный этап выступлений, по мнению Чосича, отражал недовольство населения страны ошибками власти и в определенной мере представлялся писателю оправданным. Однако дальнейший ход событий приводит Чосича к мысли, что это движение координируется контрреволюционными силами. В интервью 1980 г., данном писателем автору этих строк, Д. Чосич отмечал, что в его книге «не было ничего антисоциалистического».

Документальная проза становится важной характеристикой творчества Чосича с начала XXI в Издаются шесть томов «Записок исателя» (2000-2008), книги раздумий о судьбе сербского народа «Сербский вопрос» (2003) и «Косово» $(2004)^{2}$.

\footnotetext{
${ }^{1}$ Ћосић Д. Писци мога века. Београд, 2002. С. 70

2 Подр. см.: Шешкен А.Г. Сербская документальная проза начала XXI века // Художественный ландшафт «нулевых». Литературы Центральной и Юго-Восточной Европы в начале XXI века. М., 2014. C. $285-315$.
} 
Однако наибольшее влияние на общественное мнение в стране оказало художественное творчество писателя. Уже первый роман Чосича «Солнце далеко» (1951) вызвал бурную дискуссию в стране: впервые в сербской литературе комиссар партизанского отряда отдавал приказ расстрелять заместителя командира отряда, не запятнавшего себя ни трусостью, ни предательством. Единственная «вина» партизана Гвоздена заключалась в том, что он пытался спасти народ от уничтожения фашистами: ведь за одного убитого немца нацисты расстреливали сто сербов, и партизаны были бессильны предотвратить это. При этом, спасаясь от карателей, люди зимой бежали в леса, что вело к дополнительным огромным потерям. По мнению Гвоздена, следовало распустить отряд до весны, когда потеплеет и народ в случае необходимости сможет бежать в горы.

Естественно, что комиссар Павел рассматривает такое предложение как предательство и стремится задушить сомнение в корне. При этом, как полагает партийное руководство в романе, вопрос об оправданности действий комиссара остается открытым.

По существу, в произведении впервые была поставлена проблема соотнесенности цели и средств ее достижения. Никто не отрицал необходимости освобождения страны от оккупантов, но в то же время нельзя было не согласиться со словами Гвоздена, что свобода нужна живым, а не мертвым. Впервые в послевоенной сербской литературе Чосич утверждал исключительную ценность человеческой жизни. Этой точки зрения всегда придерживался и Чосич-политик.

В дальнейшем, размышляя о судьбе своей страны, писатель начал работу над грандиозным эпопейным циклом о жизни Сербии XX столетия. Точкой отсчета становится село Прерово, расположенное в Шумадии - центре Сербии. В романе «Корни» (1954) писатель обращается к рубежу веков, к «корням» будущих социальных конфликтов: в Прерово сталкиваются семейства богатых крестьян-торговцев Катичей и их нищих батраков Дачичей.

В 1961 г. у Чосича выходит трехтомный роман «Раздел» («Деобе»), посвященный событиям Второй мировой войны, где также появляются Катичи и Дачичи. В центре внимания писателя находится движение сербских четников, монархистов и националистов, тех, кого писатель в годы войны видел, по его собственным словам, лишь «сквозь прорезь прицела». Четники в целом представлены крайне негативно, что в свое время понравилось Тито. При этом Чосич для достижения своей цели обратился к библейским сюжетам. Так, командир четников Урош, названный воеводой Планинским, захватив в плен своего сына коммуниста Милана, казнит его, что, напоминая о жертвоприношении Авраама, придает событию символический характер. Сам Милан представлен как безмолвная невинная жертва, что позволяет вспомнить об Иисусе Христе.

Однако при всем этом писатель пытался разобраться в причинах поведения героев, раскрыть их внутренний мир, драматизм их переживаний, трагизм их судеб, парадоксальность действительности. Так, бедняк Дачич уходит к четникам для того, чтобы обрести «достойное», с его точки зрения, положение в обществе, и становится безжалостным убийцей. В конце романа герой постоянно моет руки ракией (сербской водкой), пытаясь смыть кровь невинных жертв.

В дальнейшем Чосич на время отошел от непосредственной истории Сербии и издал в 1965 г. роман-антиутопию «Сказка», где, обратившись к фантастике, обличал тоталитаризм во всех его проявлениях. Очевидно, что это произведение Чосича косвенно было направлено и против режима Тито: безымянный правитель 
воображаемой страны, обозначаемый лишь при помощи местоимения «Он», обладает абсолютной полнотой власти и убеждает своих «граждан», что их страна окружена «сатаноидами».

Во второй половине 60-х - начале 70-х гг. Чосич обратился к изображению судьбы Сербии в годы Первой мировой войны и создал первый сербский роман-эпопею «Время смерти»(I-IV, 1972-1979). В произведении были охвачены события Первой мировой войны с осени 1914 г. до зимы 1916 г., от победы сербов при реке Колубаре до «сербской Голгофы»- отступления армии и части народа под давлением превосходящих сил Германии, Австро-Венгрии и Болгарии к берегам Адриатического моря и эвакуации на «остров смерти» Корфу.

В романе Чосича представлены все социальные слои общества: от беднейших крестьян до принца-регента Александра, от простых солдат до командующего сербскими вооруженными силами воеводы Путника. При этом писатель сочетал столь важную в произведениях подобного рода документальную точность с собственным видением мира. Впоследствии сам Чосич отмечал, что, когда он писал первый и второй том «Времени смерти», документы о решающем для судьбы страны заседании Сербской народной скупщины в г. Ниш от 19-21 августа 1915 г. не были известны. Однако обнаруженный в дальнейшем протокол того заседания подтвердил точность слов писателя ${ }^{1}$.

При этом, как отмечал Чосич, дети командующего Первой армией генерала Мишича и дочь воеводы Путника выразили ему свое недовольство тем, что герои произведения не похожи на их родителей, отрицая тем самым право писателя на художественный вымысел².

Масштаб исторических событий и героев, постановка сложных философских вопросов, выявление исключительной роли народа как творца истории, глубина психологического анализа роднили произведение Чосича с «Войной и миром» Л.Н. Толстого. Однако устами генерала Живоина Мишича писатель в то же время полемизировал с Толстым, с его спокойно-эпическим восприятием мира. По мнению Мишича, у сербов, в отличие от героев русского романа, нет в запасе ни времени, ни пространства и их драматическая судьба определяется в первую очередь временем, временем смерти.

Исключительная эстетически-художественная ценность романа- эпопеи «Время смерти» во многом определила его признание со стороны читателей и критиков: о произведении сразу же были написаны десятки статей, оно выходило в Югославии огромными тиражами.

Популярность произведения была во многом обусловлена силой его воздействия на сербское национальное самосознание. Первая мировая война стала важнейшим событием в жизни Сербии после поражения от турок на Косово (1389 г.) и Первого сербского восстания (1804-1813), заложившего основы независимости страны. Героизм сербских солдат на полях сражений 1914-1918 гг. пробуждал в народе чувство национальной гордости, позволял с надеждой смотреть в будущее, убеждал в возможности серьезных преобразований.

Вместе с тем произведение Чосича предупреждало об опасности скоропалительных, основанных на эмоциях решений. Солдат-крестьянин Савва Марич, воплощение, по Чосичу, лучших национальных качеств, убеждает попавшего на фронт студента Ивана Катича в исключительной ценности ума для человека. Пла-

\footnotetext{
${ }^{1}$ Историијски роман. Београд; Сарајево, 1992-1996. С. 33

${ }^{2}$ Историијски роман. С. 32.
} 
тон Каратаев XX века убежден, что именно ум обеспечивает лучшие нравственные качества человека и предоставляет ему возможность достойной жизни.

Разумный, рациональный взгляд на действительность во «Времени смерти» исключительно важен для государственного деятеля. Вукашин Катич, депутат Скупщины, бывший краткое время министром (как впоследствии сам Чосич президентом!), «моральный меч Сербии» ${ }^{1}$, воплощение патриотизма, порядочности и ума, предлагает строить отношения с другими народами с учетом их интересов. Так, герой считает серьезнейшей ошибкой Вторую балканскую войну (1913 г.), войну между сербами и болгарами за спорную зону в Македонии. Впоследствии именно это событие подтолкнуло Болгарию к вступлению в Первую мировую войну на стороне Германии. Сам Чосич-политик предлагал еще в 1968 г. разделить Косово и Метохию между сербами и албанцами, что, скорее всего, позволило бы в дальнейшем избежать натовских бомбардировок 1999 г. и потери Сербией всей территории.

В дальнейшем в трилогии «Время зла», включающей романы «Грешник» («Грешник», 1985), «Отверженный» («Отпадник», (1986), «Верующий» («Верник», 1990) Чосич обратился к изображению политической борьбы в рядах коммунистической партии Югославии в период между двумя мировыми войнами и во время войны. Среди героев трилогии основатель династии Ачим Катич, его сын Иван, критически относящийся к сталинизму и потому воспринимаемый товарищами по коммунистической партии как отступник («грешник»). Появляется на страницах романа сын Ивана Владимир, коммунист-фанатик, а также друг Ивана Катича Богдан, социалист, а впоследствии коммунист, отступивший, как и Иван, от строгих партийных законов. Внутрипартийная борьба коммунистов дополняется борьбой с немецкими оккупантами, с гестаповцами. Многие герои романа попадают в ситуацию между двух огней, т. е. двух видов тоталитаризма, что ведет их в итоге к гибели.

В заключительной дилогии о судьбе Сербии «Время власти» (1997) и «Время власти-2» (2007) показана судьба Сербии во второй половине века. Борьба Тито со Сталиным в конце 40-х - начале 50-х гг. ХХ в. ведет к трагическому финалу для третьего поколения семьи Катичей. Иван Катич арестован и осужден на каторгу как сторонник Информбюро, а впоследствии, уже освободившись, он погибает под колесами поезда в Венеции. Его сестра Милена, пережившая гибель всей семьи и окончательно разочаровавшаяся в действительности, кончает жизнь самоубийством, повесившись на памятнике деду Ачиму Катичу. В последнем романе Чосич представляет жизнь Сербии под властью Тито.

У Чосича всегда были добрые отношения с Россией. Он высоко ценил Достоевского, был близок с Леоновым, участвовал в работе II съезда советских писателей. Его роман «Солнце далеко» был переведен в 1956 г. на русский язык и издан большим тиражом. В 1984 г. в нашей стране был опубликован роман Чосича «Корни», в 1985 г. первый и второй том романа-эпопеи «Время смерти». В 2012 г. в России был опубликован четвертый том «Записок писателя» под названием «Заметки писателя и президента Югославии 1992-1993».

В 2010 г Д. Чосичу была вручена Золотая медаль А.С. Пушкина - высшая награда I Славянского литературного форума. По словам писателя, сказанным по этому поводу, усиление России должно повлиять на судьбы всего мира².

\footnotetext{
${ }^{1}$ Ћосић Д. Време смрти. I-IV. Т. I. Ријека, 1981. С. 111.

2 Добрица Чосич. Усиление России - судьбоносный вопрос для всего мира. 24.05.2010. Интервью Н. Головкина: www.stoletie.ru/slavyanskoe_pole/dobrica_chosich_usilenije_rossii--sudbonosnyj_vopros_dla_vsego_ mira_2010-05-24.htm
} 


\section{ЛИ Т Е РАТ У РА}

Шешкен А.Г. Сербская документальная проза начала XXI века // Художественный ландшафт «нулевыХ». Литературы Центральной и Юго-Восточной Европы в начале XXI века. M., 2014. C. 285-315.

Историјски роман. Београд; Сарајево, 1992-1996.

Радуловић М. Роман Добрице Ћосића. Београд, 2005.

\section{RE F E R E N C ES}

Sheshken A.G. Serbian Documentary Prose of the early $21^{\text {st }}$ century. In: Artistic Landscape of the 2000s. Literatures of Central and South-Eastern Europe in the early $21^{\text {st }}$ century. Moscow. 2014, pp. 285-315.

Historical Novel. Beograd; Sarajevo. 1992-1996.

Radulović M. (2005) The Novel of Dobrica Cosić. Beograd.

Сведения об авторе:

Сергей Николаевич Мещеряков,

канд. филол. наук

доцент

филологический факультет

МГУ имени М.В. Ломоносова
Sergey N. Meshcheriakov,

$\mathrm{PhD}$

Associate Professor

Philological Faculty

Lomonosov Moscow State University

pionerskaya@bk.ru 